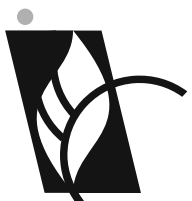

J O U R N A L

$\mathrm{O} F \bullet \mathrm{B} \mathrm{A} \mathrm{L} \mathrm{T} \mathrm{I} \mathrm{C}$

$S$ C I E N C E

EDUCATION

\section{ISSN 1648-3898}

Abstract. In Taiwan, substantial resources have been invested in training programs

for Aboriginal adolescents in response to their poor occupational achievement.

This study examined the relationships between the learning experiences of science training, vocational self-concept, and occupational aspirations among Taiwanese Aboriginal adolescents. Data were collected from a questionnaire survey of 760

Taiwanese Aboriginal adolescents who had successfully completed the science training. The results of this study demonstrated that the Taiwanese Aboriginal adolescents' learning experiences of science training directly and indirectly influenced their occupational aspirations vis-à-vis the effect on their vocational self-concept at the individual level, which in turn directly influenced their occupational aspirations. The findings suggest that the science training programs for Taiwanese indigenous youth may provide sufficient supports in

culturally responsive ways to facilitate these trainees' vocational self-concept and occupational aspirations as well as further to achieve the original goals of the science training programs.

Key words: occupational aspiration, science training, Taiwanese Aboriginal adolescents, vocational self-concept.

Ya-Ling Wu, National Pingtung University of Science \& Technology, Taiwan

Cheng-Wu Chen,

National Cheng Kung University, Taiwan Department of Maritime Information and Technology, National Kaohsiung Marine University, Taiwan

\section{EXAMINING THE LEARNING EXPERIENCES DF SLIENCE TRAINING AMDNG TAIWANESE ABDRIGINAL ADILESCENTS}

\author{
Ya-Ling Wu, \\ Cheng-Wu Chen
}

\section{Introduction}

Taiwanese Aborigines have lived on the island of Taiwan for over one thousand years. They were forced to make contact with Euro-American and Han-Chinese people approximately four hundred years ago, after which they were driven from their original living areas and migrated to higher mountains (Cheng \& Jacob, 2008). In 2012, there were 527,250 Taiwanese Aborigines, which represents $2.26 \%$ of the total population of Taiwan. Of them, $52.96 \%$ live in mountain tribal regions (Executive Yuan, 2012). The indigenous people have historically been a socioeconomically disadvantaged ethnic minority (Wang, 2009). The average income of Aboriginal families has been usually lower than that of ethnic-majority families. The rate of unemployment and underemployment among the indigenous people has far exceeded that of the majority population, and Taiwanese Aborigines have been over-represented in primarily unskilled and low-skilled occupations (Executive Yuen 2012; Wu, 2012). For improving this group's employability in response to their poor occupational achievement, the Taiwanese government has thus invested substantial resources to offer training programs in applied science especially for Aboriginal youth and also implemented affirmative action and other parity policies to engage Aboriginal youth in training programs (Council of Indigenous Peoples, 2007). In fact, training programs aim to equalize the wrongs of society and to empower all disadvantaged trainees (Johnson-Bailey \& Cerverto, 2000). However, little research has explored the implementation and the effectiveness of theses training programs especially for Aboriginal adolescents from these Aboriginal young trainees' perspective. The learning experiences of training, insofar as they pertain to Taiwanese Aboriginal youth, are the focus of this study. In the present study, learning experiences of science training refers to the culturally responsive learning experiences of vocational training in applied science among Taiwanese Aboriginal youth. 
Occupational aspirations, which are the expressed occupational goals that an individual desires to achieve, can reflect individuals' past experiences and future social mobility (Rojewski, 2005). Adolescents' occupational aspirations can significantly predict their adult educational and occupational choices and achievements (Marjoribanks, 2002; Mau \& Bikos 2000). Because occupational aspirations in adolescence can influence individuals' occupational achievement and behaviors in career development (Mau \& Bikos 2000; Super, 1990), training programs that fail to account for the occupational aspirations of Taiwanese indigenous young trainees are unlikely to improve their career outcomes (Lowe \& Tassone, 2001). Therefore, there is a critical necessity to examine the occupational aspirations among Taiwanese Aboriginal youth who participated in science training programs and further to investigate the effect of their learning experiences of science training on their occupational aspirations.

The vocational self-concept is the comprehensive perception of self related to vocational values, interests, and experiences. The development of individuals' vocational self-concept is the key indicator of their future career maturity (Super, 1990). Training programs aim not only to equip the trainees with the professional skills and knowledge but also to help them develop their vocational self-concept to fully participate in occupational development (Kirkpatrick \& Kirkpatrick, 2009). Thus, the vocational self-concept of Taiwanese Aboriginal adolescents who participated in science training programs and the effect of the training on their vocational self-concept are the focus of this study. In short, four specific objectives are investigated in this study:

- To identify the learning experiences of science training among Taiwanese Aboriginal adolescents, including curriculum and teaching, interpersonal relationship, and career interventions.

- To explore the vocational self-concept of Taiwanese Aboriginal adolescents;

- To assess the occupational aspirations of Taiwanese Aboriginal adolescents; and

- To examine the relationships between the learning experiences of science training, vocational self-concept, and occupational aspirations among Taiwanese Aboriginal adolescents.

\section{Theoretical Background and Research Hypotheses}

\section{The Developmental-Contextual Model of Career Development as the Study Framework}

Since the development of occupational aspirations is the key part of individuals' career development outcomes, the developmental-contextual model of career development by Vondracek, Lerner, and Schulenberg (1986), was applied as the framework of this study. Drawing on life-span development theories and contextualist perspectives, the approach conceptualizes development as "the interaction between a developing individual and the contextual systems" (Vondracek, Lerner, \& Schulenberg, 1986, p.5).

The person as an active producer of the development. The developing individual is embedded in an interconnected set of contexts, and his/her characteristics play a critical role in his/her own development. Individuals provide feedback for themselves or provide a basis for their own development (Vondracek, 1998).

Contexts contributing to individuals' development. The contexts consist of multiple systems, including proximal and distal systems. Proximal systems include the immediate social and material settings in which the developing individual is situated. Distal systems include factors relating to social position (e.g., socioeconomic status and ethnicity) which the individual cannot control. The set of proximal contexts has a direct impact on individuals' career development, while the distal systems have an indirect impact that is often mediated by the more proximal contexts (Vondracek, Lerner, \& Schulenberg, 1986).

The dynamic interaction between the individual and the contexts. There is a dynamic and integrated relationship among multiple levels of analysis. Variables from any of these levels might contribute to individuals' development, and no single level of analysis may operate separately (Bronfenbrenner \& Ceci, 1994; Vondracek, Lerner, \& Schulenberg, 1986). 


\section{The Relationships among Taiwanese Aboriginal Adolescents' Learning Experiences of Science Training, Vocational Self-concept, and Occupational aspirations}

Guided by the developmental-contextual model of career development, the present study investigated the relationships among Taiwanese Aboriginal adolescents'learning experiences of science training, vocational self-concept, and occupational aspirations. In this study, Taiwanese Aboriginal adolescents' learning experiences of science training were viewed as the contextual-level factor influencing their occupational aspirations, and their vocational self-concept was posited as the individual-level factor contributing to their occupational aspirations.

While some theoretical literature has demonstrated that training programs influence Aborigines' career development, many empirical studies have tended to emphasize the structural and physical variables of training programs, such as size, location, and kinds of program (Gelade \& Stehlik 2004), rather than the essential elements of trainees' learning, such as curriculum, teaching, interpersonal interactions, and career interventions. Recently, a small number of studies examining these core dimensions of learning experiences of training have indicated that culturally responsive training programs could promote the career development of Australian Aborigines and Native Americans (Alliman-Brissett \& Turner, 2005; Craven, et al., 2005). Furthermore, previous studies have shown that supportive learning experiences of training and education have an important influence on adolescents' self-concept (e.g., Garg, Melnson, \& Levin, 2002).

Vocational self-concept is an individual's perception of his/her self related to work or occupations and an individual's occupational aspirations are representative of his/her vocational self-concept (Super, 1990). Some studies have suggested that vocational self-concept is an important determinant of individuals' occupational aspirations (Garg et al, 2007; Patton \& Creed 2007).

\section{Research Hypotheses}

Based on the above-mentioned literature review, the research hypotheses of this study are shown in Figure 1 and Table 1. Overall, this study aims to test the three hypotheses.

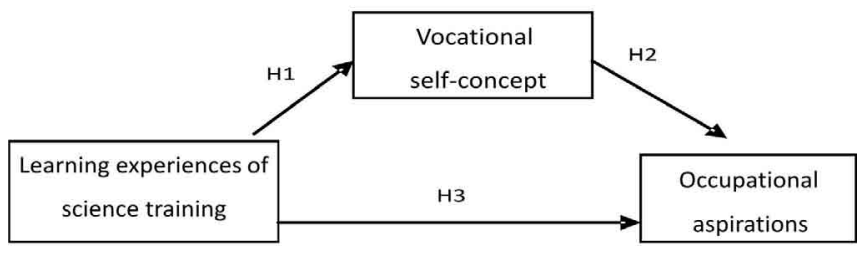

Figure 1: Research hypotheses.

Table 1. The hypotheses to be tested.

H1: Culturally responsive learning experiences of science training positively influence vocational self-concept.

H2: Vocational self-concept positively influences occupational aspirations.

H3: Culturally responsive learning experiences of science training positively influence occupational aspirations. 


\section{Methodology of Research}

\section{Participants}

For the purposes of the study, a questionnaire survey was used to collect data, and the study population consisted of Taiwanese Aboriginal adolescents at the age of 15-24 who had completed the vocational training programs in applied science from 2010 to 2012. Anonymous questionnaires were distributed to 920 participants in the selected training centers, and $82.6 \%(\mathrm{~N}=760)$ of the questionnaires were returned and usable. Of the participants, 477 are males (62.8\%), and 283 are females (37.2\%) with 288 (37.9\%) participants at the age of 15-18 and 472 (62.1\%) at the age of 19-24 years. Altogether, 214 participants (28.2\%) were from 5 centers in the northern region, $113(14.9 \%)$ were from 3 centers in the central region, 160 (21.1\%) were from 4 centers in the southern region, and 273 (35.8\%) from 5 centers in the eastern region. Overall, $73.7 \%(n=560)$ of the participants lived in tribal regions, $18.8 \%(n=143)$ lived near the indigenous people in non-tribal regions, and $7.5 \%(n=57)$ lived near non-indigenous people in non-tribal regions.

\section{Instruments and Data Analysis}

The scales of the study were adapted primarily from various published sources (e.g., Garg, et al., 2007; Koksal \& Cakiroglu, 2010; Marjoribanks, 2002; Wu \& Lou, 2012). Each item of the scales was measured on a four-point Likert scale ( $1=$ strongly disagree to $4=$ strongly agree). A pilot study was conducted on all the scales, and the item analysis and principal component analysis via Direct Oblimin rotation were conducted. The Cronbach's a values for reliability in all scales were higher than 0.70 , and the loadings of all items were greater than 0.50 . Thus, all of the scales had good reliability and validity.

Leaning Experiences of Science training were measured by a 19-item scale $(\alpha=0.88)$ which assessed the participants' perception of the level of supports their vocational training programs in applied science provided for them in the culturally responsive ways (e.g., "I have good relationships with my instructors"). The scale included three subscales: (1) curriculum and teaching $(a=0.80)$ : the curriculum and teaching support provided for the participants in the training programs; $(2)$ interpersonal relationship ( $a=0.76$ ): the quality of the participants' interpersonal relationships in the training; and (3) career interventions $(a=0.79)$ : the career interventions the training programs provided for the participants.

Vocational self-concept was measured using a 8-item scale $(a=0.82)$ to assess the level of each participant's perception of self related to jobs or professions. The scale included two dimensions: 1 . self-awareness $(a=0.74)$ : the participants' understanding of their vocational interests, ability, and aptitude; 2. vocational awareness: the participants' understanding of the occupations which they wished to enter in the future $(a=0.74)$.

Occupational aspirations were measured with a 17 -item scale $(\alpha=0.82)$ that assessed the degree to which the individuals aspired to enter occupations with high socioeconomic status in the future. The scale included three dimensions: 1. professionalism ( $a=0.84)$ : the level of professionalism they wish to achieve; 2 . leadership ( $a=0.88$ ): the degree of leadership in the occupation they wish to own; 3 . position $(a=0.76)$ : the level of the position in the occupation they wish to have .

In this study, SPSS 17.0 was used as the statistic software. Descriptive statistics, one-sample t-test, dependent-sample one-way ANOVA, dependent-sample t-test, and path analysis of multiple regression analysis were employed to analyze the data.

\section{Results of Research}

\section{Learning Experiences of Science Training}

As seen in Table 2, the participants scored 2.84 on the learning experiences of science training scale, higher than the scale's median value (2.5), which suggests that the Taiwanese Aboriginal adolescents perceived that they were provided with the moderately high level of supports in the culturally 
(P. $312-321$ )

responsive ways during their science training ( $M=2.84$, compared to $2.5, t=19.96, p<0.001)$. Of the three dimensions, the level of the curriculum and teaching supports was higher $(M=2.97)$ than the level of the interpersonal relationship supports $(M=2.86)$, and the level of the career intervention supports was the lowest $(M=2.74)(F=992.13 ; p<0.001)$.

Table 2. Means, standard deviations and dependent-sample one-way ANOVA of the learning experiences of science training $(\mathrm{N}=760)$.

\begin{tabular}{|c|c|c|c|c|}
\hline Dimensions & M & SD & $F$ & Post hoc comparison \\
\hline $\begin{array}{l}\text { Learning experiences of science } \\
\text { training }\end{array}$ & 2.84 & 0.47 & & $1>2 ; 1>3 ; 2>3$ \\
\hline Curriculum and teaching & 2.97 & 0.55 & $\mathrm{~F}=992.13^{* * *}$ & 1. Curriculum and teaching \\
\hline Interpersonal relationship & 2.86 & 0.60 & & $\begin{array}{l}\text { 2. Interpersonal relationship } \\
\text { 3. Career intervention }\end{array}$ \\
\hline Career intervention & 2.74 & 0.53 & & \\
\hline
\end{tabular}

\section{Vocational Self-Concept}

As seen in Table 3, the participants scored 2.86 on vocational self-concept scale, higher than the scale's median value (2.5), which suggests that the Taiwanese Aboriginal adolescents had moderately high level of vocational self-concept $(M=2.86$, compared to $2.5, t=18.38, p<0.001)$. Of the two dimensions, the level of the self-awareness was higher $(M=3.00)$ than the level of vocational awareness $(M=2.71)$ $(t=17.60 ; p<0.001)$.

Table 3. Means, standard deviations and dependent-sample t-test of vocational self-concept $(\mathrm{N}=760)$.

\begin{tabular}{|c|c|c|c|c|}
\hline Dimensions & M & SD & $t$ & Post hoc comparison \\
\hline $\begin{array}{l}\text { Learning experiences of science } \\
\text { training }\end{array}$ & 2.86 & 0.54 & & $1>2$ \\
\hline Self-awareness & 3.00 & 0.62 & $t=17.60^{* * *}$ & $\begin{array}{l}\text { 1. Self-awareness } \\
\text { 2. Vocational awareness }\end{array}$ \\
\hline Vocational awareness & 2.71 & 0.54 & & \\
\hline
\end{tabular}

\section{Occupational Aspirations}

As seen in Table 4, the participants scored 3.04 on the occupational aspiration scale, higher than the scale's median value (2.5), which suggests that the Taiwanese Aboriginal adolescents had high occupational aspirations $(M=3.04$, compared to $2.5, t=29.20, p<0.001)$. Of the three dimensions, the level of position they wished to achieve was higher $(M=3.46)$ than the level of the professionalism they wished to achieve $(M=3.17)$, and the level of the leadership they wished to get was the lowest $(M=2.49)$ $(F=973.84 ; p<0.001)$. 
Table 4. Means, standard deviations and dependent-sample one-way ANOVA of occupational aspirations $(N=760)$.

\begin{tabular}{lccll}
\hline \multicolumn{1}{c}{ Dimensions } & M & SD & \multicolumn{1}{c}{ Post hoc comparison } \\
\hline Occupational aspirations & 3.04 & 0.51 & & $1>2 ; 1>3 ; 3>2$ \\
Professionalism & 3.17 & 0.61 & & $\begin{array}{l}\text { 1. Professionalism } \\
\text { 2. Leadership }\end{array}$ \\
Leadership & 2.49 & 0.54 & 3. Position \\
Position & 3.46 & 0.58 & \\
\hline$" p<0.001$ & & &
\end{tabular}

The Relationships between the Learning Experiences of Science Training, Vocational Self-Concept, and Occupational Aspirations

This study used path analysis of multiple regression analysis to examine the relationships between the learning experiences of science training, vocational self-concept, and occupational aspirations among Taiwanese Aboriginal adolescents.

The assumptions of the regression model were checked. Because the zero-order correlations coefficients among the independent variables were all less than 0.32 , the Variance Inflation Factor (VIF) values ranged between 1.037 and 1.230 , and tolerance statistics ranged between 0.683 and 0.752 , there was no evidence to suggest that the data suffered from multicollinearity. In other words, there was no strong correlation between two or more predictors in the regression model. The Durbin-Watson statistic was also between 1 and 2 (1.68), implying that errors in the regression were independent (Tabachnick \& Fidell, 2007). Standardized residuals were examined to detect the presence of outliers. Three cases were determined to have standardized residuals between 2.981 and 3.076. Because none of those three cases had a Cook's distance (a measure of the overall influence of a case on the model) greater than 1 and the sample size was large, none of them had undue influence on the regression model (Field, 2005). The assumptions of normality, linearity, and homoscedasticity were checked by considering standardized residual scatter plots to examine whether the residuals were normally distributed around the predicted employability scores. It was discovered that the residuals had a linear relationship with the predicted employability scores. Overall, all assumptions were therefore met (Tabachnick \& Fidell, 2007).

The regression results showed that the learning experiences of science training had a positive effect on the vocational self-concept, and explained $38.4 \%$ of the variance of the vocational self-concept (Table 5). The learning experiences of science training and vocational self-concept both had positive effects on Taiwanese Aboriginal youth's occupational aspirations, and explained $58.2 \%$ of the variance of the occupational aspirations (Table 6).

Table 5. Multiple regression coefficients for the effect of the learning experiences of science training on vocational self-concept $(\mathrm{N}=760)$.

\begin{tabular}{ccccc}
\hline Predictors & R2 & $\boldsymbol{F}$ & $\boldsymbol{B}$ & $\boldsymbol{\beta}$ \\
\hline $\begin{array}{c}\text { Learning experiences of } \\
\text { science training }\end{array}$ & 0.384 & $472.321^{* * *}$ & 0.301 & 0.620 \\
\hline **** $p<0.001$ & & & &
\end{tabular}


(P. $312-321$ )

Table 6. Multiple regression coefficients for the effect of the learning experiences of science training and vocational self-concept on occupational aspirations $(\mathrm{N}=760)$.

\begin{tabular}{lllll}
\hline \multicolumn{1}{c}{ Predictors } & $\mathbf{R}^{2}$ & $\boldsymbol{F}$ & $\boldsymbol{B}$ & $\boldsymbol{\beta}$ \\
\hline $\begin{array}{l}\text { Learning experiences of science } \\
\text { training }\end{array}$ & 0.481 & $472.321^{* * *}$ & 0.896 & 0.443 \\
Vocational self-concept & & & 0.398 & 0.405 \\
\hline
\end{tabular}

Overall, all of the three hypotheses concerning the relationships between the variables were supported at the 0.01 significance level $(\mathrm{H} 1$ : the learning experiences of science training $\rightarrow$ vocational self-concept, $\beta=0.620 ; \mathrm{H} 2$ : vocational self-concept $\rightarrow$ occupational aspirations, $\beta=0.443 ; \mathrm{H} 3$ : the learning experiences of science training $\rightarrow$ occupational aspirations, $\beta=0.405)$. The results showed that, the participants' learning experiences of science training positively affected their vocational self-concept; the participants' vocational self-concept positively affected their occupational aspirations; through science training, the participants'learning experiences of science training both directly and indirectly and positively affected their occupational aspirations. The relationships among these variables are shown in Figure 2. The estimates of the direct and indirect effects of the learning experiences of science training and vocational self-concept on Taiwanese' Aboriginal adolescents' occupational aspirations are shown in Table 7. Of the two variables, the learning experiences of science training had the greater impact on Taiwanese' Aboriginal adolescents' occupational aspirations (estimate $=0.680$ ).

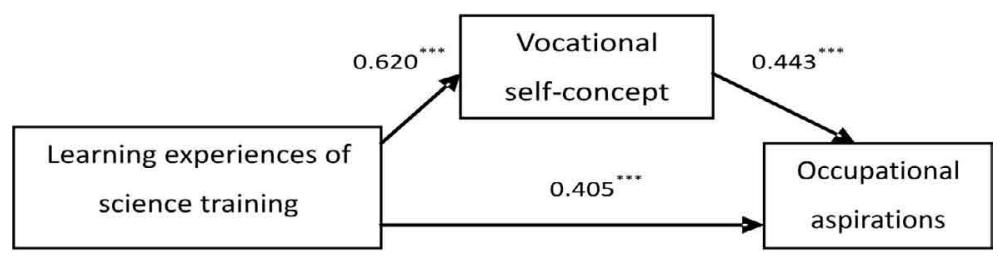

Figure 2: Results of testing the hypotheses.

Table 7. Estimates of the direct and indirect effects of the learning experiences of science training and vocational self-concept on occupational aspirations.

\begin{tabular}{lccc}
\hline \multicolumn{1}{c}{ Casual path } & Direct effect & Indirect effect & Total effect \\
\hline $\begin{array}{l}\text { Vocational self-concept } \rightarrow \text { occupa- } \\
\text { tional aspirations }\end{array}$ & 0.443 & - & 0.443 \\
$\begin{array}{l}\text { The learning experiences of science } \\
\text { training } \rightarrow \text { occupational aspirations }\end{array}$ & 0.405 & $0.620^{*} 0.443=0.275$ & 0.680 \\
\hline
\end{tabular}

\section{Discussion}

The results of this study provided empirical support for the hypotheses of the relationships among Taiwanese Aboriginal adolescents'learning experiences of science training, vocational self-concept, and occupational aspirations based on the developmental-contextual model of career development. The results demonstrated that the learning experiences of science training, a proximal contextual factor, directly and indirectly influenced the occupational aspirations vis-à-vis the effect on vocational selfconcept at the individual level, which directly influenced the occupational aspirations. 
The results of this study empirically indicated that the supports of science training in culturally responsive ways had a strong impact on the vocational self-concept and occupational aspirations among the Taiwanese Aboriginal young trainees. It suggests that it is critically important to provide culturally responsive supports for Taiwanese Aboriginal adolescent trainees in the science training programs, including the supports of the curriculum and teaching, interpersonal relationship, and career intervention. However, it is noteworthy that although specialists in multicultural education suggest that the cultural heritage of ethnic minority groups should be cherished and not act as a barrier to their career development (Gay, 2000), training centers in Taiwan typically implement the mainstream-centric training programs for Aboriginal trainees without considering their specific cultural needs (Wu, 2012). Furthermore, the result of the study suggests that the training programs for Taiwanese Aboriginal adolescents should not only emphasize providing the professional knowledge and skills for the trainees but also pay attention to facilitate their psychological and social capability.

It was found that regarding the learning experiences of science training, the Taiwanese Aboriginal youth tended to experience less supports of career intervention than those supports of curriculum and teaching and interpersonal relationship. The previous study also has showed that the training programs in Taiwan only offer training in professional skills and do not provide either a clear employment pathway or post-training support. This deficiency hampers the trainees to gain employment after they have completed their training (Cheng \& Gao, 2010). However, the study on the African American adolescents have indicated that the sufficient and culturally responsive career intervention of training programs could promote these adolescents' career development (Alliman-Brissett \& Turner, 2005). Therefore, the science training programs for Taiwanese Aboriginal youth may include more culturally responsive career intervention, such as the supports of job search.

This study found that the Taiwanese Aboriginal adolescents' vocational self-concept, which was affected by their learning experiences of science training, had a significant effect on their occupational aspirations. This result obviously supports the concept that a developing individual, interacting with contextual systems, plays a crucial role in career development (Vondracek et al., 1986). Compared to the Han Chinese, Taiwanese Aborigines are likely to maintain a lower vocational self-concept because of their low educational and occupational achievement (Chiang, 2003). However, this study found that the Taiwanese Aboriginal youth who had finished the science training programs tended to have moderately high vocational self-concept. This result also supports the positive effect of the science training programs on Taiwanese Aboriginal adolescents' vocational self-concept.

In this study, it also found that the level of the participants'self-awareness was higher than that of their vocational awareness. It suggests that the Taiwanese Aboriginal youth tended to understand their vocational interests, ability, and aptitude more than the occupations which they wished to enter in the future. The possible explanation of this result may be that the training programs in applied science for Taiwanese Aboriginal youth might emphasize the training of professional skills without providing the sufficient information about the occupations they may choose in the future (Shan, 2010). The acquisition and possession of vocational information are crucial to the individuals'occupational preparation (Winch, 2004). Vocational information can allow individuals to determine whether his/her career choices will be appropriately suited to his/her vocational interests, personality characteristics, and career development (Grotevant \& Durrett, 1980). Individuals have been found to limit their occupational choices by selectively eliminating various possible occupations based on inadequate or incorrect vocational information, and it then becomes the reason for rejecting an occupation (Brown, 2002). Thus, in order to facilitate the employment of Taiwanese Aboriginal young trainees, the training programs for Taiwanese Aboriginal youth may provide sufficient information about the occupations which the trainees are prepared for.

This study found that the Taiwanese indigenous youth tended to demonstrate the moderately high level of occupational aspirations. Specifically, in the future occupations, they wished to get the high positions most while they wished to get the leadership least. This result seems to reflect the naturally optimistic philosophy of the Taiwanese Aborigines, who enjoy the freedom of their own lives instead of the governorship of other people's lives or work (Wang, 2009). 


\section{Conclusions}

This study aimed to explore the relationships between the learning experiences of science training, vocational self-concept, and occupational aspirations among Taiwanese Aboriginal adolescents based on the developmental-contextual model of career development. The results demonstrated that the Taiwanese Aboriginal youth's learning experiences of science training directly and indirectly influenced their occupational aspirations vis-à-vis the effect on vocational self-concept, which directly influenced their occupational aspirations. This study represents an important extension of previous research in that it suggested that Taiwanese Aboriginal youth's learning experiences of science training had a great impact on both their vocational self-concept and occupational aspirations.

In fact, training programs aim to equalize the wrongs of society and to empower all disadvantaged trainees (Johnson-Bailey \& Cerverto, 2000). Therefore, the science training programs for Taiwanese indigenous youth should provide sufficient supports in culturally responsive ways, particularly the supports of career intervention and the information about the occupations the Aboriginal young trainees may enter.

Furthermore, cultural competence interventions are needed to facilitate training instructors to reflect on the value of training programs for indigenous adolescents and to understand their cultures. Instructors should also be capable of delivering training in ways that recognize the cultures of indigenous trainees in order to facilitate these trainees'vocational self-concept and occupational aspirations as well as further to achieve the original goals of the training programs.

Nevertheless, in this study, the use of only one reporter for all variables in this study may not collect data that reflect the responses of people contributing to the participants'learning of training, vocational self-concept, and occupational aspirations. Additionally, this limitation also raises the possibility of common method variance (Kline, 2005). To provide the comprehensive understanding of the complexity of Aboriginal adolescents' learning and development and minimize the inflated method variance, it is necessary for further research to include multiple informants in the theoretical model, such as training instructors and parents.

\section{References}

Alliman-Brissett, A. E., \& Turner, S. L. (2005). Promoting the career aspirations of American Indian youth. CURA Reporter: Center for Urban and Regional Affairs, 35 (2), 20-24.

Bronfenbrenner, U., \& Ceci, S. J. (1994). Nature-nurture reconceptualized in developmental perspective: A bioecological model. Psychological Review, 101, 568-586.

Brown, D. (2007). Career Information, Career Counselling, and Career Development ( $9^{\text {th }}$ Ed.). Boston, MA : Allyn and Bacon.

Cheng, S. Y., \& Jacob, W. J. (2008). American Indian and Taiwan Aboriginal education: Indigenous identity and career aspirations. Asia Pacific Education Review, 9 (3), 233-247.

Cheng, Z. U., \& Gao, M. H. (2010). The evaluation of foreign spouses' participation in vocational training. Taipei, Taiwan: Ministry of Interior.

Chiang, M. I. (2003). Taiwanese Aboriginal high school students' cultural identity and life adjustment. Unpublished Master Thesis. National Taitung University, Taitung, Taiwan.

Council of Indigenous Peoples (2007). The employment of Taiwanese Aborigines in 2007. Taipei, Taiwan: Council of Indigenous Peoples.

Executive Yuan (2012). The Demographic survey of Taiwan Aborigines in recent ten years. Taipei, Taiwan: Executive Yuan.

Field, A. (2005). Discovering statistics using SPSS. London: Sage.

Garg, R., Melnson, S., \& Levin, E. (2007). Educational aspirations of male and female adolescents from single-parent and two biological parent families: A Comparison of influential factors. Journal of Youth and Adolescence, 36 (8), 1010-1023. doi: 10.1007/s10964-006-9137-3.

Gay, G. (2000). Culturally responsive teaching: Theory, research, and practice. New York, N. Y.: Teachers College Press.

Gelade, S., \& Stehlik, T. (2004). Exploring locality: The impact of context on indigenous vocational education and training aspirations and outcomes. Adelaide, Australia: National Centre for Vocational Education Research (NCVER).

Grotevant, H. D., \& Durrett, M. E. (1980). Occupational knowledge and career development in adolescence. Journal of Vocational Behavior, 17, 171-182. 
John-Steiner, V., \& Mahn, H. (1996). Sociocultural approaches to learning and development: A Vygotskian framework. Educational Psychologist, 31, 191-206.

Kirkpatrick, D. L., \& Kirkpatrick, J. D. (2009). Evaluating training programs: The four levels ( ${ }^{\text {rd }}$ Ed.). San Francisco: Berrett-Koehler.

Koksal, M. S., \& Cakiroglu, J. (2010). Development of nature of science scale (NSS) for advanced science students. Journal of Baltic Science Education, 9 (2), 87-98.

Lowe, K., \& Tassone, J. (2001). Aboriginal career aspirations program: School and community career education. New South Wales, Australia: NSW Board of Studies Project.

Marjoribanks, K. (2002). Family background, individual and environmental influences on adolescents' aspiration. Educational Studies, 28 (1), 33-46. doi: 10.1080/03055690120090361.

Mau, W. C., \& Bikos, L. H. (2000). Educational and vocational aspirations of minority and female students: A longitudinal study. Journal of Counseling and Development, 78, 186-194.

Patton, W. A., \& Creed, P. (2007). Occupational aspirations and expectations of Australian adolescents. Australian Journal of Career Development, 16 (1), 46-59.

Rojewski, J. W. (2005). Occupational aspirations: Constructs, meaning, and application. In: S. D. Brown \& R. W. Lent (Eds). Career development and counselling: Putting theory and research to work (pp. 131-154). Hoboken, N. J.: John Wiley \& Sons.

Shan, C. L. (2010). A study of the vocational training, employment guidance and practicable strategies for Taiwanese Aborigines. Feng Chia Journal of Humanities and Social Sciences, 20, 227-259.

Super, D. E. (1990). A life-span, life-space approach to career development. In D. Brown, L. Brooks and Associates (Eds.). Career choice and development囚Applying contemporary theories to practice (pp.197-261). San Francisco: Jossey-Bass.

Tabachnick. B. G. \& Fidell, L. S. (2007). Using multivariate analysis. Boston : Pearson/Allyn \& Bacon.

Vondracek, F. W. (1998). Career development: A lifespan perspective. International Journal of Behavioral Development, 22, 1-6.

Vondracek, F. W., Lerner, R. M., \& Schulelberg, J. E. (1986). Career development: A life-span developmental approach. Hillsdale, NJ: Erlbaum.

Wang, S. S. (2009). The societies and cultures of Taiwanese Aborigines. Taipei, Taiwan: Linking.

Winch, C. (2004). What do teachers need to know about teaching? A critical examination of the occupational knowledge of teachers. British Journal of Educational Studies, 52 (2), 180-196.

Wu, Y. L. (2012). Schooling experiences and career aspirations of indigenous vocational high school students: A case study in Taiwan. Asia Pacific Journal of Education, 32 (1), 1-15.

Wu, Y. L., \& Lou, S. J. (2012). Understanding the educational aspirations of Taiwanese Aboriginal adolescents based on the developmental-contextual model of career development. The Asia-Pacific Education Researcher, 21 (3), 434-441.

Received: February 20, 2013

Accepted: April 28, 2013

Ya-Ling Wu

Cheng-Wu Chen

(corresponding

author)
Ph. D. in Education, Associate Professor, Graduate Institute of Technological and Vocational Education, National Pingtung University of Science \& Technology, No.1, Shuefu Road, Neipu, Pingtung 912 Taiwan, R.O.C.

E-mail: karin@mail.npust.edu.tw

Website: http://oar.npust.edu.tw/user/1676

Researcher, Data Analysis Center, National Cheng Kung University, Tainan, Taiwan 701 R.O.C.

Professor, Department of Maritime Information and Technology,

National Kaohsiung Marine University, Taiwan

E-mail: chengwu@mail.nkmu.edu.tw 